DOI: https://doi.org/10.31933/jimt.v3i1 Received: 11 Juni 2021, Revised: 25 Agustus 2021, Publish: 8 September 2021

JIMT
JURNASTI
TERAPAN ILMU MANAJEMEN

\title{
PENGARUH DISIPLIN KERJA DAN GAYA KEPEMIMPINAN TERHADAP KINERJA KARYAWAN DAN MOTIVASI KERJA SEBAGAI VARIABEL INTERVENING PADA DINAS PARIWISATA KOTA SAWAHLUNTO
}

\section{Idham Fahmi ${ }^{1}$}

Mahasiswa Program Doktor Manajemen Fakultas Ekonomi dan Bisnis Universitas Putra Indonesia YPTK Padang, email: idham.fahmi@gmail.com

\section{Corresponding author: Idham Fahmi ${ }^{1}$}

\begin{abstract}
Abstrak: Penelitian ini bertujuan untuk menguji seberapa besar Pengaruh Gaya Kepemimpinan Dan Disiplin Kerja Terhadap Kinerja Karyawan Dan Motivasi Kerja Sebagai Variabel Intervening Pada Dinas Pariwisata Kota Sawahlunto. Metode pengumpulan data melalui survei dan menyebarkan kuisioner, dengan sampel 50 responden yang di dapat dengan rumus sampel jenuh pada populasi pegawai Dinas Pariwisata kota Sawahlunto sebanyak 50 karyawan. Metode analisis yang digunakan adalah inner model dan path coefficients. Hasil penelitian yang didapatkan berdasarkan path coefficients diperoleh: (a) Terdapat pengaruh positif yang signifikan secara parsial Disiplin Kerja terhadap Kinerja Karyawan, (b) Terdapat pengaruh positif yang signifikan secara parsial Disiplin Kerja terhadap Motivasi Kerja, (c) Tidak terdapat pengaruh positif yang signifikan secara parsial penilaian kinerja terhadap pengembangan karir, (d) Tidak terdapat pengaruh positif yang signifikan secara parsial Gaya Kepemimpinan terhadap Motivasi Kerja (e) Tidak terdapat pengaruh positif yang signifikan secara parsial Motivasi Kerja terhadap Kinerja Karyawan. Akhirnya penulis menyarankan sebaiknya karyawan memberikan masukan dan saran kepada pihak Dinas Pariwisata Kota Sawahlunto mengenai peningkatan Kinerja karyawan dan sebagainya, agar dinas terkait mampu meningkatkan fasilitas dan lingkungan yang aman bagi karyawan dalam bekerja guna dapat mempertahankan bahkan meningkatkan kinerja karyawan. Disarankan pada peneliti yang berminat melanjutkan penelitian ini, untuk menambah variabel diluar model ini.
\end{abstract}

Kata kunci: Disiplin Kerja, Gaya Kepemimpinan, Kinerja Karyawan dan Motivasi Kerja

\section{PENDAHULUAN}

Dalam menghadapi arus globalisasi Sumber Daya Manusia (SDM) memegang peranan yang sangat dominan dalam aktivitas atau kegiatan perusahaan. Berhasil atau tidaknya perusahaan dalam mencapai tujuan yang ditetapkan sebelumnya sangat tergantung pada kemampuan sumber daya manusianya (karyawan) dalam menjalankan tugas-tugas yang diberikan kepadanya. Oleh karena itu, setiap perusahaan perlu memikirkan bagaimana cara yang dapat dilakukan untuk mengembangkan sumber daya manusianya agar dapat mendorong kemajuan 
bagi perusahaan dan bagaimana caranya agar karyawan tersebut memiliki produktivitas yang tinggi, yang tentunya pimpinan perusahaan perlu memotivasi karyawannya. Adapun cara meningkatkan mutu sumber daya manusia adalah dengan memperhatikan gaya kepemimpinan dan disiplin karyawan.

Pergerakan roda suatu organisasi sangat ditentukan oleh faktor kepemimpinan. Kepemimpinan merupakan hal yang dominan dalam suatu organisasi karena kepemimpinan bukan saja melakukan perencanaan ataupun pelaksanaan jalanya organisasi, tetapi juga dapat mengorganisir anggota dalam mencapai tujuan organisasi. Salah satu permasalahan manajemen yang bersifat kritis pada saat ini adalah kepemimpinan karena mampu atau tidak mampunya seseorang pemimpin dapat melaksanakan tugas nya sebagai pemimpin suatu organisasi dan adanya pemimpin yang kurang dihargai oleh bawahanya.

Disisi lain tenaga kerja merupakan salah satu asset perusahaan yang paling utama, dari itu tenaga kerja perlu dibina secara baik dari seorang pemimpin. Pembinaan yang baik dapat menciptakan tenaga kerja yang mempunyai komitmen dan kegairahan dalam pekerjaan serta mempunyai komitmen organisasi yang tinggi sehingga kinerja kerja dapat ditingkatkan.

Peningkatan kinerja karyawan akan membawa kemajuan bagi perusahaan untuk dapat bertahan dalam suatu persaingan lingkungan kerja yang tidak stabil. Oleh karena itu upaya-upaya untuk meningkatkan kinerja karyawan merupakan tantangan manajemen yang paling serius karena keberhasilan untuk mencapai tujuan dan kelangsungan hidup perusahaan tergantung pada kualitas kinerja sumber daya manusia yang ada didalamnya.

\section{KAJIAN TEORI \\ Kinerja}

Kinerja sering diartikan sebagai pencapaian tugas, dimana karyawan dalam bekerja harus sesuai dengan program kerja organisasi untuk menunjukkan tingkat kinerja organisasi dalam mencapai visi, misi, dan tujuan organisasi. Menurut Riva'i (2013:548), Kinerja merupakan perilaku nyata yang ditampilkan setiap orang sebagai prestasi kerja yang dihasilkan oleh karyawan sesuai dengan perannya dalam perusahaan. Kinerja pegawai menunjuk kemampuan pegawai dalam melaksanakan keseluruhan tugas-tugas yang menjadi tanggung jawabnya. Tugas tersebut biasanya berdasarkan indikator-indikator keberhasilan yang sudah diterapkan. Sebagai hasilnya akan diketahui bahwa seorang pegawai masuk dalam tingkatan kerja tertentu. Kinerja dapat dikelompokkan melampaui target, sesuai target atau dibawah target.Pengertian kinerja merupakan gambaran mengenai tingkat pencapaian pelaksanaan suatu program kegiatan atau kebijakan dalam mewujudkan sasaran, tujuan, visi, dan misi organisasi yang dituangkan melalui perencanaan strategis suatu organisasi (Moeheriono, 2010:60). Faktor yang mempengaruhi kinerja menurut Suprihatiningrum ( 2012:22) yaitu Motivasi, kepuasan kerja, tingkat stress, kondisi fisik pekerjaan, dan desain pekerjan.

Menurut Robbins (2006:206), indikator untuk mengukur kinerja karyawan yaitu:

1. Kualitas

2. Ketepatan Waktu

3. Inisiatif

4. Kemampuan

5. Komunikasi

\section{Motivasi Kerja}


Motivasi adalah seperangkat faktor yang dapat membangkitkan, mengarahkan dan memelihara perilaku seseorang untuk memilih jalan tertentu dalam mencapai tujuan (Sugiyono,2013:134). Manullang (2006:166) motivasi kerja adalah sesuatu yang menimbulkan dorongan dan semangat kerja. Seorang pemimpin harus memberikan perhatian kepada pegawai tentang pentingnya tujuan dari suatu pekerjaan agar timbul minat pegawai terhadap pelaksanaan kerja.Menurut(Ardana dkk, 2012:193) jenis motivasi dapat dibagi tiga yaitu: (1) Material incentive : pendorong yang dapat dinilai dengan uang,(2) Semi material incentive,(3) Non material incentive : yang tak dapat dinilai dengan uang Teori motivasi menurut Maslow Maslow dalam Reksohadiprojo dan Handoko ( 1996 ) membagi kebutuhan manusia seperti kebutuhan fisiologis, kebutuhan rasa aman, kebutuhan sosial, penghargaan, dan aktualisasi diri.

\section{Gaya Kepemimpinan}

Thoha (2001:49) menjelaskan bahwa gaya kepemimpinan merupakan norma perilaku yang digunakan seseorang pada saat orang tersebut mencoba mempengaruhi perilakuorang lain. Perilaku tersebut biasa di pengaruhi oleh beberapa faktor seperti nilai- nilai, asumsi,persepsi, harapan, maupun sikap-sikap yang ada dalam diripemimpin. Berbagai penelitian tentang gaya kepemimpinan yang dilakukanpara ahli mendasarkan pada asumsi bahwa pola perilaku tertentu pemimpin dalam mempengaruhi bawahan ikut menentukan efektivitasnya dalam pemimpin.Gaya kepemimpinan adalah perilaku atau cara yang dipilih dan dipergunakan pemimpin dalam mempengaruhi pikiran, perasaan, sikap, dan perilaku para anggota organisasi atau bawahan. Hubungan pimpinan dan bawahan dapat diukur melalui penilaian pekerja terhadap gaya kepemimpinan para pemimpin dalam mengarahkan dan membina para bawahannya untuk melaksanakan pekerjaan. Jenis gaya kepemimpinan Gaya Kepemimpinan yang Otoriter,Gaya Pemimpin yang Demokratis, Gaya Kepemimpinan Kendali Bebas. Menurut Sutanjar dan Saryono(2019:322) kepemimpinan dapat dikatakan sebagai cara dari seorang pemimpin dalam mengarahkan, mendorong dan mengatur seluruh unsur - unsur di dalam kelompok, atau organisasinya untuk mencapai suatu tujua norganisasi yang diinginkan sehingga menghasilkan kinerja pegawai yang maksimal. Kepemimpinan merupakan suatu bentuk strategi atau teori memimpin yang tentunya dilakukan oleh orang yang biasa kita sebut pemimpin.Pimpinan yang baik akan mampu menularkan optimisme dan pengetahuan yang dimiliki bawahannya dapat melaksanakan pekerjaan dengan baik. Setiap pimpinan akan memperlihatkan kepemimpinannya lewat ucapan, sikap dan tingkah lakunya yang dirasa oleh dirinya sendiri maupun orang lain.

\section{Disiplin Kerja}

Disiplin merupakan bentuk pelatihan yang menegakkan peraturan- peraturan perusahaan (Mathis dan Jackson, 2002:314). Menurut Handoko (2008:208) disiplin adalah kegiatan manajemen untuk menjalankan standar-standar organisasi. Ada dua tipe kegiatan pendisiplinan, yaitu preventif dan korektif.

\section{Conceptual Framework}

Berdasarkan rumusan masalah penulisan artikel ini baik dari buku dan artikel yang relevan, maka di perolah kerangka artikel ini seperti di bawah ini. 


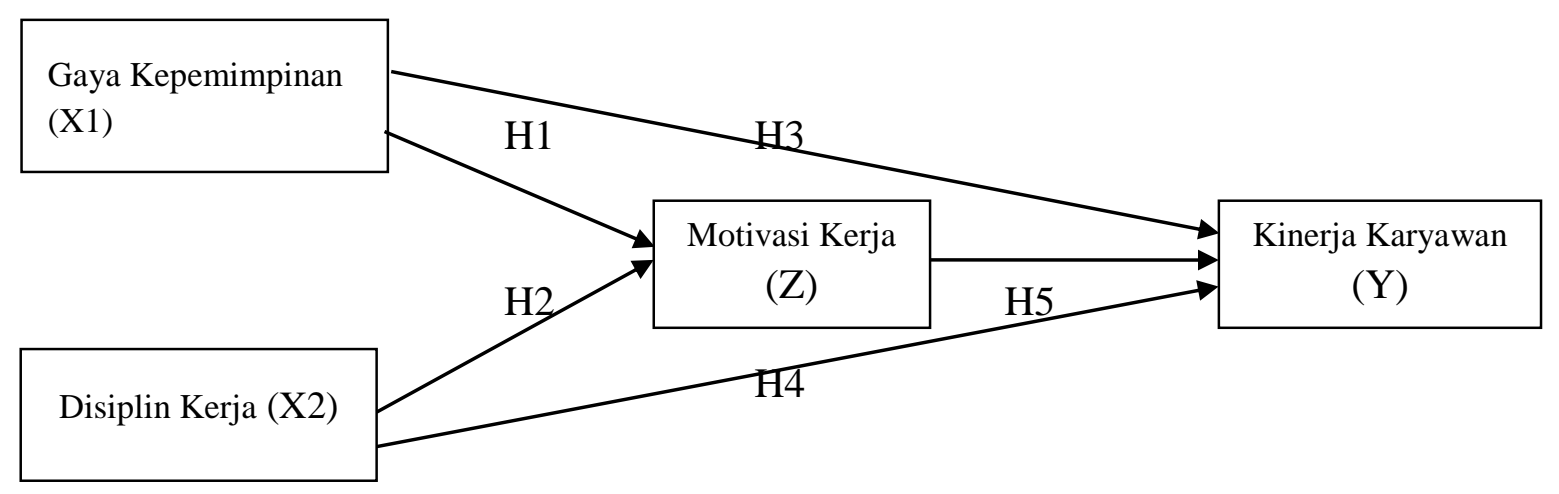

Figure 1: Conceptual Framework

\section{METODE PENELITIAN Populasi}

Menurut (Sugiyono, 2016:80), populasi adalah wilayah generalisasi yang terdiri dari obyek/subobyek yang mempunyai kualitas dan karakteristik tertentu yang ditetapkan oleh penelitian untuk dipelajari dan kemudian ditarik kesimpulannya.Dalam penelitian ini yang menjadi populasi adalah seluruh pegawai dinas Pariwisata.

\section{Sampel}

Berdasarkan penelitian ini karena jumlah populasinya tidak lebih besar dari 100 orang responden, maka penulis mengambil $100 \%$ jumlah populasi. Dengan demikian penggunaan seluruh populasi tanpa harus menarik sampel penelitian sebagai unit observasi disebut sebagai teknik sensus.

\section{Metode Analisis}

\section{Analisis Structrul Equation Modeling (SEM) dengan Partial Least Square (PLS)}

Menurut (Sarwono \& Narimawati, 2014:2) Prosedur regresi partial least squares (PLS) digunakan untuk mempekirakan kuadrat terkecil parsial model-model regresi atau dikenal sebagai proyeksi terhadap struktur laten.pls adalah teknik yang merupakan alternative untuk regresi kuadrat terkecil biasa (ordinary least square/ OLS), korelasi kanonik,atau pemodelan persamaan structural (structural e quation modeling/SEM.). Selain itu, PLS sangat berguna ketika beberapa variabel bebas orediktor saling berkorelasi sangat tingi,atau ketika jumlah predicator melebihi jumlah kasus.PLS mengabungkan fitur-fitur dari analisis komponen utama (principal component analysis) dan regresi berganda. Prosedur pengunaan PLS di lakukan dalam dua tahap .pertama,dengan mengeluarkan serangkaian factor laten yang men jelaskan sebanyak mungkin kovarians factor laten yang menjelaskan sebanyak mungkin kovarians anatara variabel dependen dengan mengunakan dekomposisi variabel independen.

\section{Analisa Deskriptif}

Analisis ini bermaksud untuk menggambarkan karakteristik masing-masing variabel penelitian. Dengan cara menyajikan data ke dalam tabel distribusi frekuensi, yang menggamarkan tingkat frekuensi dan persentase $(\%)$ dari masing-masing jawaban responden pada skala lakert serta menginterpretasikannya. Analisis ini tidak menghubung-hubungkan satu variabel dengan variabel lainnya dan tidak membandingkan satu variabel dengan variabel lainnya. Untuk mendapatkan rata-rata skor masing-masing indikator dalam pernyataan yang 
terdapat dalam kuisioner dipakai rumus berikut (Arikunto, 2002) :

$$
\begin{gathered}
\text { Rata-rata skor }=\frac{\sum f i x \text { Wo }}{\sum f} \\
\text { Dimana }: \sum f i=\text { Total frekuensi ke i } \\
\text { Wo }=\text { Bobot } \\
\sum f=\text { Total frekuens }
\end{gathered}
$$

Sedangkan untuk mencari tingkat capaian responden (TCR) digunakan rumus berikut (Arikunto, 2002) :

$$
\mathrm{TCR}=\frac{\text { Rata }- \text { Rata Skor }}{5} \times 100
$$

Dimana: TCR = tingkat pencapaian jawaban responden

Arikunto (2002), menyatakan bahwa kriteria nilai tingkat capaian responden (TCR) dapat diklasifikasikan sebagai berikut :

\begin{tabular}{llll}
\multicolumn{2}{l}{ Persentase Pencapaian } & Kriteria \\
$90 \%$ & - & $100 \%$ & : Sangat Baik \\
$80 \%$ & - & $89,99 \%$ & : Baik \\
$65 \%$ & - & $79,99 \%$ & $:$ Cukup baik \\
$55 \%$ & - & $64,99 \%$ & $:$ Kurang baik \\
$0 \%$ & - & $54,99 \%$ & $:$ Tidak baik
\end{tabular}

\section{Statistik Inferensial}

Statistik Inferensial sering juga disebut statistik induktif atau statistik probabilitas merupakan teknik statistik yang digunakan untuk menganalisis data sampel dan hasilnya diberlakukan untuk populasi (Sugiyono, 2018). Statistik ini akan cocok 50 digunakan bila sampel diambil dari seluruh populasi yang jelas dan teknik pengambilan sampel dari populasi itu dilakukan secara acak.

Sesuai dengan hipotesis yang telah dirumuskan, maka dalam penelitian ini analisis data statistik inferensial diukur dengan menggunakan software SmartPLS mulai dari pengukuran model (outer model), evaluasi struktur model (inner model), pengujian hipotesis dan model analisis persamaan struktural

1. Pengukuran Model (Outer Model)

Menurut Abdillah dan Jogiyanto (2015) outer model atau model pengukuran menggambarkan hubungan antar blok indikator dengan variabel latennya. Model ini secara spesifik menghubungkan antar variabel laten dengan indikator-indikatornya atau dapat dikatakan bahwa outer model mendefinisikan bagaimana setiap indikator berhubungan dengan variabel lainnya. Uji yang dilakukan pada outer model yaitu: 
a. Convergent Validity, dinilai berdasarkan loading factor (korelasi antara skor item atau skor komponen dengan skor konstruk). Indikator dianggap valid jika memiliki nilai AVE (Average Variance Extranced) diatas 0,5 atau memperlihatkan seluruh outer loading dimensi variabel memiliki nilai loading > 0,5 sehingga dapat disimpulkan bahwa pengukuran tersebut memenuhi kriteria validitas konvergen (Ghozali 2018). Nilai AVE merupakan rata-rata presentase skor varian yang diekstraksi dari seperangkat variabel laten yang diestimasi melalui loading Standarized indikatornya dalam proses iterasi alogaritma dalam PLS (Jogiyanto, 2018).

b. Discriminant Validity, dinilai berdasarkan cross loading, model mempunyai discriminant validity yang cukup jika nilai cross loading 51 antara konstruk lebih besar dari nilai cross loading antara konstruk dengan konstruk lainnya dalam model (Jogiyanto, 2018).

c. Menurut Jogiyanto (2018) uji reliabilitas menggunakan nilai Cronbach's Alpha dan Composite Reliability. Cronbach's Alpha untuk mengukur batas awah nilai reliabilitas suatu konstruk sedangkan Composite Reliability mengukur nilai sesungguhnya reliabilitas suatu konstruk. Namun Composite Reliability dinilai lebih baik dalam mengestimasi konsistensi internal suatu konstruk. Suatu konstruk atau variabel dikatakan reliabel jika memberikan nilai Cronbach's Alpha> 0,7 dan Composite Reliability> 0,7.

2. Evaluasi Struktur Model (Inner Model)

Menurut Abdillah dan Jogiyanto (2015) model struktural (Inner model) merupakan model struktural untuk memprediksi hubungan kausalitas antar variabel laten. Dalam mengevaluasi struktur model pada penelitian ini digunakan Coefficient of Determination (R2) dan Path Coefficient ( $\beta$ ). Hal ini digunakan untuk melihat dan meyakinkan hubungan antara konstruk yang dibuat (Jogiyanto, 2018).

a. Coefficient of Determination (R2)

Koefisien determinasi pada konstruk disebut nilai R-square. Model struktural (inner model) merupakan model struktural untuk memprediksi hubungan kausalitas antar variabel laten. Goodness of fit model diukur menggunakan Rsquare variabel laten dependen dengan interpretasi yang sama dengan regresi Qsquare predictive relevance untuk model struktural, mengukur seberapa baik nilai observasi dihasilkan oleh model dan juga estimasi parameternya. Nilai Qsquare 52 lebih besar dari 0 (nol) memperlihatkan bahwa model mempunyai nilai predictive relevance, sedangkan nilai Q-square kurang dari 0 (nol) memperlihatkan bahwa model kurang memiliki predictive relevance. Namun, jika hasil perhitungan memperlihatkan nilai Qsquare lebih dari 0 (nol), maka model layak dikatakan memiliki nilai prediktif yang relevan (Ghozali, 2018).

b. Path Coefficient ( $\beta$ )

Merupakan nilai koefisien jalur atau besarnya hubungan atau pengaruh konstruk laten, dilakukan dengan prosedur Bootstraping Path Coefficients merupakan suatu metode penelitian yang digunakan untuk menguji kekuatan hubungan langsung dan tidak langsung diantara berbagai variabel.(Herani, 2018)

Konstruk dan dimensi-dimensi yang akan diteliti dari modelteoritistelahdikembangkanpadatelaahteoritisdanpengembanganhipotesis.

Konstruk-konstrukyangterbentukadalahkonstrukendogenyaitu organizational citizenship behavior. Konstruk eksogendalampenelitianiniadalahPengalaman Kerja $\left(\mathrm{X}_{1}\right)$, Beban Kerja $\left(\mathrm{X}_{2}\right)$, Prestasi Kerja (Y), dan Organizational Citizenship Behavior $(Z)$ mengintervensikeempat variable eksogen diatas terhadap variable 
endogen.

Pengujian hipotesis ( $\beta, \gamma$ dan $\lambda$ ) dilakukan dengan metode resampling bootstrap. Statistik uji yang digunakan adalah statistik $t$ atau uji $t$, dengan hipotesis statistik sebagai berikut:

1. Hipotesis statistik untuk outer model: $\mathrm{H} 0: \lambda \mathrm{i}=0 \mathrm{H} 1: \lambda \mathrm{i} \neq 0$

2. Hipotesis statistik untuk inner model: variabel laten eksogen terhadap endogen: $\mathrm{H} 0: \gamma \mathrm{i}=0 \mathrm{H} 1: \gamma \mathrm{i} \neq 0$

3. Penerapan metode resampling, memungkinkan berlakunya data terdistribusi bebas (distribution free), tidak memerlukan asumsi distribusi normal, serta tidak memerlukan sampel yang besar (sampel minimum 30).

\section{HASIL DAN PEMBAHASAN}

\section{Penilaian Average Variance Extracted (AVE)}

Selanjutnya untuk menilai tingkat kevalidan semua item pernyataan yang membangun masing-masing variabel penelitian yang sudah valid di atas, juga akan dinilai nilai Average Variance Extracted (AVE) sebagai salah satu indikator yang menunjukkan semua item yang valid memang terukur. Suatu konstruk atau variabel dikatakan memiliki validitas yang tinggi jika nilainya berada diatas 0,50. Berikut akan disajikan nilai AVE untuk seluruh konstruk (variabel) pada Tabel 1:

Tabel 1 : NilaiAverage Variance Extracted (AVE)

\begin{tabular}{|l|l|}
\hline Variabel & AVE \\
\hline Disiplin Kerja & 0.735 \\
\hline Gaya Kepemimpinan & 0.642 \\
\hline Kinerja Karyawan & 0.764 \\
\hline Motivasi Kerja & 0.762 \\
\hline
\end{tabular}

Sumber : Lampiran Hasil Pengolahan Data,Tahun 2021

Berdasarkan diatas dapat disimpulkan bahwa semua konstruk atau variabel penelitian di atas telah memenuhi kriteria validitas yang baik. Hal ini ditunjukkan dengan nilai Average Variance Extracted(AVE)di atas 0.50 sebagaimana kriteria yang direkomendasikan.

\section{Penilaian Discriminant Validity}

Selanjutnya penilaian outer model juga dapat dinilai melalui Discriminant validity. Dimana Discriminant validity dilakukan untuk memastikan bahwa setiap konsep dari masing konstruk atau variabel laten berbeda dengan konstruk/variabel lainnya. Model mempunyai discriminant validity yang baik dalam penelitian ini dinilai melalui perbandingan nilai korelasi masing-masing konstruk laten antar konstruk endogen dengan nilai akar AVE. Jika nilai akar AVE setiap konstruk besar dari nilai korelasi konstruk laten maka dapat dikatakan outer model yang dihasilkan sudah baik, begitu juga sebaliknya jika nilai akar AVE setiap konstruk rendah dari nilai korelasi konstruk laten maka dapat dikatakan outer model yang dihasilkan masih belum baik karena mengandung adanya item pernyataan yang tidak valid. Berikut hasil pengujian discriminant validity: 
Tabel 2 : Nilai Discriminant Validity

\begin{tabular}{|c|c|}
\hline Variabel & Akar AVE \\
\hline Disiplin Kerja & 0.857 \\
\hline Gaya Kepemimpinan & 0.801 \\
\hline $\begin{array}{l}\text { Kinerja Karyawan } \\
\text { Motivasi Kerja }\end{array}$ & $\begin{array}{l}0.874 \\
0.873\end{array}$ \\
\hline
\end{tabular}

Sumber : Lampiran Hasil Pengolahan Data,Tahun 2021

Berdasarkan hasil perhitungan pada Tabel 2 di atas, dapat disimpulkan bahwa penilai outer model untuk semua konstruk atau variabel telah memenuhi kriteria validitas yang baik. Hal ini terlihat dari nilai akar AVE lebih besar dari nilai korelasi konstruk laten dengan konstruk endogen.

\section{Penilaian Reliabilitas}

Setelah diketahui tingkat kevalitan data, maka langkah berikut adalah mengetahui tingkat keandalan data atau tingkat reliabel dari masing-masing konstruk atau variabel. Penilaian ini dengan melihat nilai composite reliability dan nilai crombachs alpha.Nilaisuatukonstrukdikatakanreliabeljikamemberikan nilai composite reliability dan crombach alpha >0,70 (Werts et al.1979 dalam Ghozali, 2006). Berikut hasil uji pada Tabel3

Tabel 3 : Nilai Reliabelitas

\begin{tabular}{|l|l|l|l|}
\hline Konstruk (Variabel) & $\begin{array}{l}\text { Composite } \\
\text { Reliability }\end{array}$ & $\begin{array}{l}\text { Crombachs } \\
\text { Alpha }\end{array}$ & Keterangan \\
\hline Disiplin Kerja & 0.943 & 0.926 & Reliabel \\
\hline Gaya Kepemimpinan & 0.926 & 0.908 & Reliabel \\
\hline Kinerja Karyawan & 0.975 & 0.972 & Reliabel \\
\hline Motivasi Kerja & 0.927 & 0.895 & Reliabel \\
\hline
\end{tabular}

Sumber : Lampiran Hasil Pengolahan Data,Tahun 2021

Berdasarkan output SmartPLS pada Tabel 4.3 di atas, telah ditemukan nilai composite reliability dan nilai crombach alpha masing-masing konstruk atau variabel besar dari 0,60 . Oleh karena itu, semua persyaratan yang menilai tingkat reliablitas dari semua item pernyataan yang valid untuk semua variabel penelitian, dapat dikatakan sudah reliable atau handal dan dapat digunakan untuk pengujian hipotesis penelitian.

\section{Pengujian Inner Model (Structural Model)}

Proses pengujian selanjutnya adalah pengujian inner model atau model struktural yang bertujuan untuk mengetahui hubungan antar konstruk atau pengaruh antar variabel penelitian 
sebagaimana yang telah dihipotesiskan. Tahap awal dari model struktural adalahmengevaluasi model dengan memperhatikannilai $R$-Square untuk konstruk endogen dari pengaruh yang diterimanya dari konstruk eksogen. Berikut model struktural hasil uji dengan menggunakan SmartPLS :

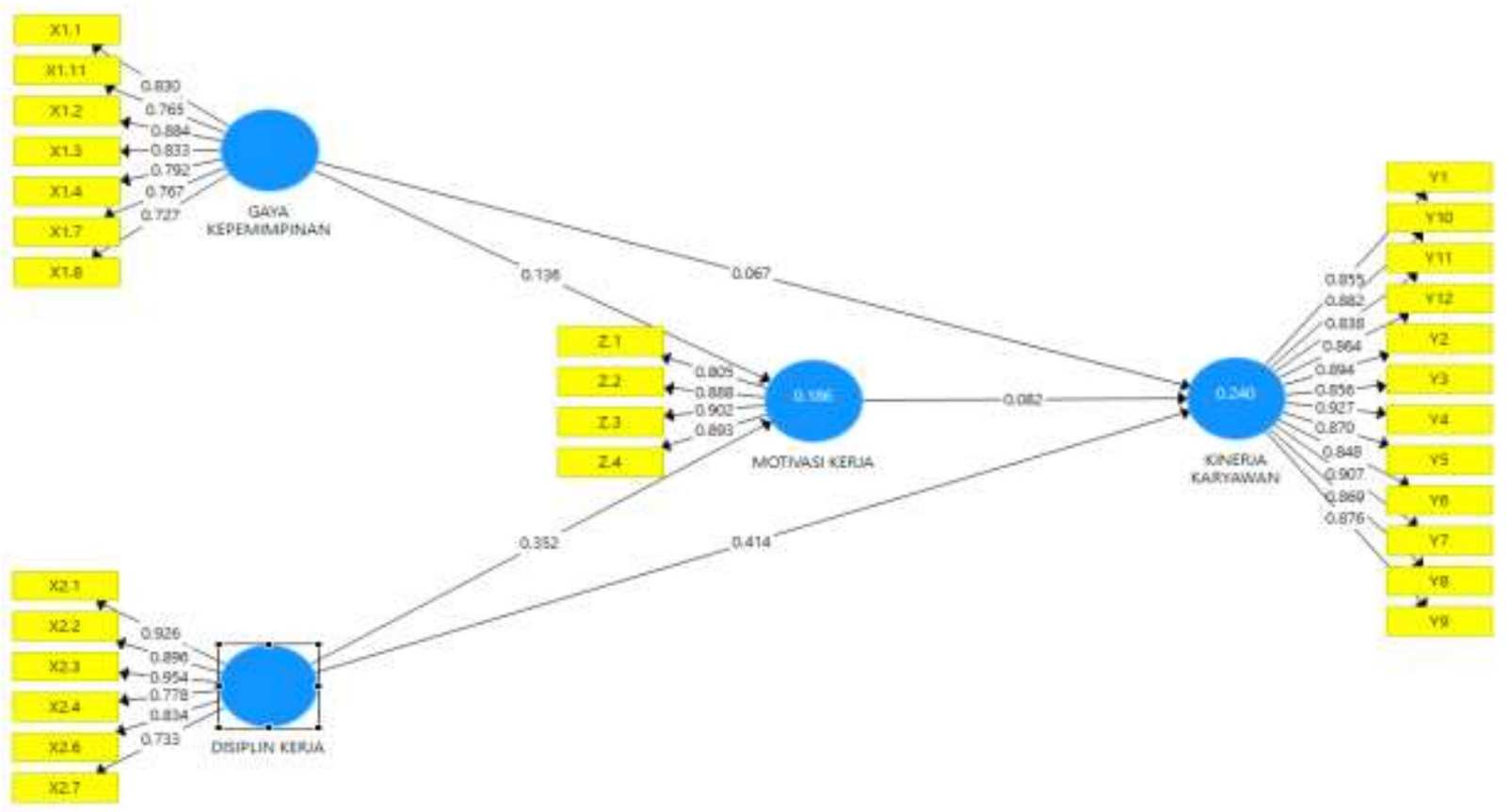

Sumber : Lampiran Hasil Pengolahan Data,Tahun 2021

\section{Gambar 2 : Struktural Model}

Berdasarkan Gambar 2, model struktur diatas dapat dibentuk Persamaan Model sebagai berikut :

a. Model Persamaan I, merupakan gambaran besarnya pengaruh konstruk gaya kepimimpinan dan disiplin kerja terhadap motivasi kerja sebagai variabel intervening dengan koefisien yang ada ditambah dengan tingkat error yang merupakan kesalahan estimasi atau yang tidak bisa dijelaskan dalam model penelitian.

Motivasi kerja $=\beta_{1}$ gaya kepemimpinan $+\beta_{2}$ disiplin kerja $+\mathrm{e}_{1}$ atau Motivasi kerja $=0,136$ gaya kepemimpinan $+0,352$ disiplin kerja $+\mathrm{e}_{1}$

b. Model Persamaan II, merupakan gambaran besarnya pengaruh konstruk gaya kepimimpinan dan disiplin kerja dan motivasi kerja dengan kinerja karyawan dengan masing-masing koefisien yang ada untuk masing-masing konstruk ditambah dengan error yang merupakan kesalahan estimasi

Kinerja karyawan $=\beta_{1}$ gaya kepemimpinan $+\beta_{2}$ disiplin kerja $+\beta_{3}$ motivasi kerja + 
$\mathrm{e}_{1}$

Kinerja karyawan $=0.067$ gaya kepemimpinan+ 0,414 disiplin kerja $+0,067$ motivasi kerja $+\mathrm{e}_{1}$

Berikutnya sebagaimana yang dijelaskan sebelumnya penilaian inner model akan dievaluasi melalui nilai $R$-Squared,untuk menilai pengaruh konstruk laten eksogen tertentu terhadap konstruk laten endogen apakah mempunyai pengaruh yang substantive. Berikut estimasi $R$-Square pada Tabel 4 :

Tabel. 4 : Evaluasi Nilai $R$ Square

\begin{tabular}{|l|l|l|}
\hline No & Variabel & $\boldsymbol{R}$ Square \\
\hline 1 & Motivasi kerja & 0.186 \\
\hline 2 & Kinerja Karyawan & 0.240 \\
\hline
\end{tabular}

Sumber : Lampiran Hasil Pengolahan Data, Tahun 2021

Pada Tabel 4,terlihat nilai $R$-Square konstruk Motivasi kerja 0,186 atau sebesar 18,6\%, yang mengambarkan besarnya pengaruh yang diterimanya oleh konstruk Motivasi kerja dari konstruk gaya kepemimpinan dan disiplin kerja atau merupakan pengaruh secara simulatan konstruk penilaian gaya kepemimpinan dan disiplin kerja terhadap motivasi kerja Sementara nilai $R$-Square untuk konstruk Kinerja karyawan sebesar 0,240 atau sebesar 24,0\% menunjukkan besarnya pengaruh yang diberikan oleh konstruk gaya kepemimpinan, disiplin kerja dan motivasi kerja dalam menjelaskan atau mempengaruhi kinerja pegawai. Semakin tinggi nilai $R$-Square maka semakin besar kemampuan konstruk eksogen tersebut dalam menjelaskan variabel endogen sehingga semakin baik persamaan struktural yang terbentuk.

\section{Pembahasan Hipotesis}

Pengujian hipotesis ini bertujuan untuk mengetahui sejauh mana pengaruh variabel bebas dan intervening terhadap variabel terikat. Berikut hasil pengujian SmartPLS yang disajikan pada Tabel 5:

Tabel. 5 : ResultFor Inner Weights

\begin{tabular}{|c|c|c|c|c|c|}
\hline No & Uraian & $\begin{array}{l}\text { Original } \\
\text { Sample } \\
\text { (O) }\end{array}$ & $\begin{array}{l}\text { Standard } \\
\text { Deviatio } \\
n \\
(\text { STDEV) }\end{array}$ & $\begin{array}{l}P \\
\text { Value }\end{array}$ & Ket \\
\hline 1. & $\begin{array}{l}\text { Disiplin Kerja - Kinerja } \\
\text { Karyawan }\end{array}$ & 0.414 & 0.158 & 0.009 & $\begin{array}{l}\text { Hipotesi } \\
\mathrm{s} \\
\text { Diterima }\end{array}$ \\
\hline 2. & $\begin{array}{l}\text { Disiplin Kerja - Motivasi } \\
\text { Kerja }\end{array}$ & 0.352 & 0.127 & 0.006 & $\begin{array}{l}\text { Hipotesi } \\
\text { S } \\
\text { Diterima }\end{array}$ \\
\hline 3. & $\begin{array}{l}\text { Gaya Kepemimpinan - Kinerja } \\
\text { Karyawan }\end{array}$ & 0.067 & 0.173 & 0.697 & $\begin{array}{l}\text { Hipotesi } \\
\text { s Ditolak }\end{array}$ \\
\hline
\end{tabular}




$$
\begin{array}{|l|l|l|l|l|l|l|}
\text { 4. } \quad \begin{array}{l}
\text { Gaya Kepemimpinan } \\
\text { Motivasi Kerja }
\end{array} & \begin{array}{l}
0.136 \\
\text { 5. } \quad \begin{array}{l}
\text { Motivasi Kerja }- \\
\text { Karyawan }
\end{array}
\end{array} \mid \begin{array}{l}
\text { Kinerja } \\
0.082
\end{array} & 0.126 & 0.514 & \begin{array}{l}
\text { Hipotesi } \\
\text { s Ditolak } \\
\text { s Ditolak }
\end{array}
\end{array}
$$

Sumber : Lampiran Hasil Pengolahan Data, Tahun 2021.

Hasil pengujian data dengan menggunakan SmartPLS pada nomor 1, menemukan nilai koefisien Disiplin Kerja - Kinerja Karyawan sebesar 0.414 yang merupakan besarnya pengaruh yang diberikan konstruk Disiplin Kerja terhadap Kinerja Karyawan Dimana nilai standar error sebesar 0.158 merupakan tingkat kesalahan estimasi yang tidak dapat dijelaskan oleh konstruk ini, sedangkan P Value 0.009 lebih kecil dari pada alpha 5\%. Dengan demikian dapat disimpulkan hipotesis 1 diterima, dengan kata lain terdapat pengaruh positif yang signifikan Disiplin Kerja terhadap Kinerja Karyawan.

Hasil pengujian data dengan menggunakan SmartPLS pada nomor 2, menemukan nilai koefisien Disiplin Kerja - Motivasi Kerja sebesar 0.352 yang merupakan besarnya pengaruh yang diberikan konstruk Disiplin Kerja terhadap Motivasi Kerja Dimana nilai standar error sebesar 0.127 merupakan tingkat kesalahan estimasi yang tidak dapat dijelaskan oleh konstruk ini, sedangkan P Value 0.006 lebih kecil dari pada alpha 5\%. Dengan demikian dapat disimpulkan hipotesis 2 diterima, dengan kata lain terdapat pengaruh positif yang signifikan Disiplin Kerja terhadap Motivasi Kerja.

Hasil pengujian data dengan menggunakan SmartPLS pada nomor 3, menemukan nilai koefisien Gaya Kepemimpinan - Kinerja Karyawan sebesar 0.067 yang merupakan besarnya pengaruh yang diberikan konstruk Gaya Kepemimpinan terhadap Kinerja Karyawan Dimana nilai standar error sebesar 0.173 merupakan tingkat kesalahan estimasi yang tidak dapat dijelaskan oleh konstruk ini, sedangkan P Value 0.697 lebih besar dari pada alpha 5\%. Dengan demikian dapat disimpulkan hipotesis 3 ditolak, dengan kata lain tidak terdapat pengaruh positif yang signifikan penilaian kinerja terhadap pengembangan karir.

Hasil pengujian data dengan menggunakan SmartPLS pada nomor 4, menemukan nilai koefisien Gaya Kepemimpinan - Motivasi Kerja sebesar 0,136 yang merupakan besarnya pengaruh yang diberikan konstruk Gaya Kepemimpinan terhadap Motivasi Kerja Dimana nilai standar error sebesar 0.144 merupakan tingkat kesalahan estimasi yang tidak dapat dijelaskan oleh konstruk ini, sedangkan P Value 0.344 lebih besar dari pada alpha 5\%. Dengan demikian dapat disimpulkan hipotesis 4 ditolak, dengan kata lain tidak terdapat pengaruh positif yang signifikan Gaya Kepemimpinan terhadap Motivasi Kerja.

Hasil pengujian data dengan menggunakan SmartPLS pada nomor 5, menemukan nilai koefisien Motivasi Kerja - Kinerja Karyawan sebesar 0.082 yang merupakan besarnya pengaruh yang diberikan konstruk Motivasi Kerja terhadap Kinerja Karyawan Dimana nilai standar error sebesar 0.126 merupakan tingkat kesalahan estimasi yang tidak dapat dijelaskan oleh konstruk ini, sedangkan P Value 0.514 lebih besar dari pada alpha 5\%. Dengan demikian dapat disimpulkan hipotesis 5 ditolak, dengan kata lain tidak terdapat pengaruh positif yang signifikan Motivasi Kerja terhadap Kinerja Karyawan.

\section{KESIMPULAN DAN SARAN Kesimpulan}


Penelitian ini bertujuan untuk mengetahui bahwa Pengaruh Gaya Kepemimpinan Dan Disiplin Kerja Terhadap Kinerja Karyawan Dan Motivasi Kerja Sebagai Variabel Intervening Pada Dinas Pariwisata Kota Sawahlunto. Responden penelitian ini berjumlah 50 karyawan. Berdasarkan pada data yang telah dikumpulkan dan pengujian yang telah dilakukan terhadap permasalahan dengan menggunakan smart PLS, maka dapat diambil kesimpulan sebagai berikut:

1. Terdapat pengaruh positif yang signifikan Disiplin Kerja terhadap Kinerja Karyawan dimana nilai signifikan $0,009<0,05$.

2. Terdapat pengaruh positif yang signifikan Disiplin Kerja terhadap Motivasi Kerja dimana nilai signifikan $0,006<0,05$.

3. Tidak terdapat pengaruh positif yang signifikan penilaian kinerja terhadap pengembangan karir dimana nilai signifikan 0,697>0,05.

4. Tidak terdapat pengaruh positif yang signifikan Gaya Kepemimpinan terhadap Motivasi Kerja. dimana nilai signifikan 0,344>0.05.

5. Tidak terdapat pengaruh positif yang signifikan Motivasi Kerja terhadap Kinerja Karyawan. dimana nilai signifikan 0,514>0,05.

\section{Saran} berikut :

Berdasarkan kesimpulan di atas, maka penulis akan memberikan saran - saran sebagai

1. Bagi pegawai

Diharapkan kepada karyawan memberikan masukan dan saran kepada pihak Dinas

Pariwisata Kota Sawahlunto mengenai peningkatan Kinerja karyawan dan sebagainya, agar dinas terkait mampu meningkatkan fasilitas dan lingkungan yang aman bagi karyawan dalam bekerja guna dapat mempertahankan bahkan meningkatkan kinerja karyawan.

2. Bagi Institusi

Temuan penelitian ini dapat menjadi masukan dan pertimbangan bagi pihak-pihak terkait dalam meningkatkan, mengarahkan organisasi menjadi organisasi yang kompetitif yang mampu menjawab semua tantangan termasuk juga dengan tantangan global yang sedang akan berlangsung. Melalui perbaikan faktor-faktor yang mempengaruhi Kinerja karyawan dan motivasi kerja karyawan dalam melaksanakan fungsi dan tugasnya demi tercapainya tujuan organisasi.

\section{DAFTAR PUSTAKA}

Fahmi, I. (2015). Manajemen Strategis.

Hendriani, A. R. S. Dan S. (2016). Pengaruh Kompetensi, Komitmen Dan Pengembangan Karir Terhadap Kinerja Karyawan Pt. Bank Raykat Indonesia (Persero) Kantor Wilayah Pekanbaru. Jurnal Tepak Manajemen Bisnis. Volume Vii, Nomor 1.

Herani, J. (2018). Pengaruh Kualitas Pelayanan Terhadap Loyalitas Merek Melalui Kepuasan 
Pelanggan (Studi Pada Pelanggan Bengkel Yamaha 2 Mei Bandar Lampung). Universitas Lampung, 301(5), 83.

Mangkunegara, A. A. A. P. (2016). Manajemen Sumber Daya Manusia Perusahaan. Bandung: Pt. Remaja Rosdakarya.

Murwansyah. (2016). Manajemen Sumber Daya Manusia Bandung: Alfabeta.

Nurismalatri, E. P. Dan. (2018). Analisis Faktor Penentu Keputusun Konsumen Muslim Dalam

Memilih Jasa Perbankan: Bank Syariah Vs Bank Konvensional. Jurnal Lembaga Keuangan Dan Perbankan. Volume 3, Nomor 1.

Sarwono, Jonathan, \& Narimawati, U. (2014). Membuat Skripsi,Tesis,Dan Disertasi (T. A. Prabawati (Ed.)). C.V Andi Offset.

Sugiyono. (2016). Metode Penelitian Kuantitatif,Kualitatif,Dan R\&D (Cet. 23). Alfabeta,Cv. Suryadi, D. (2018). Pengaruh Kualitas Kerja Dan Efesiensi Kerja Terhadap Produktivitas Kerja Bintara Tni-Ad Di Makorem 032/Wirabraja. Jurnal Manajemen Dan Kewirausahaan. Volume 9, Nomor 1.

Sutrisno, E. (2016). Manajemen Sumber Daya Manusia. Jakarta: Media Grup. 